\title{
ASSESSMENT OF KNOWLEDGE ABOUT THE ENERGY VALUE OF SELECTED MEALS BY THE HELICOPTER EMERGENCY MEDICAL SERVICE (HEMS) TEAM
}

\author{
Agata GAŹDZIŃSKA' ${ }^{1}$, Robert GAŁAZZKOWSKI², Paweł JAGIELSKI ${ }^{3}$, Mariusz WYLEŻOł ${ }^{1}$ \\ ${ }^{1}$ Military Institute of Aviation Medicine, Warsaw, Poland \\ ${ }^{2}$ Department of Emergency Medical Services, Medical University of Warsaw, Poland \\ ${ }^{3}$ Human Nutrition Department, Faculty of Health Science, Jagiellonian University, Medical College, Poland
}

Source of support: Own sources

Author's address: A. Gaździńska, Institute of Aviation Medicine, Krasińskiego 54/56 Street, 01-755 Warsaw, Poland, e-mail: agazdzinska@wiml.waw.pl

Introduction: Introduction: An appropriate level of nutrition knowledge resulting in proper eating is one of the components of health behaviours. The profession of both paramedics and pilots should involve taking greater care of one's health. The aim of this study was to assess the Polish Medical Air Rescue paramedics and pilots' nutrition knowledge with respect to the energy value of selected meals present in the daily diet.

Methods: The assessment of the energy value of selected foods was carried out among all Polish Helicopter Emergency Medical Service (HEMS) pilots and paramedics (66 pilots, 65 paramedics) aged 27-59. Their nutritional status was assessed based on the results of anthropometric tests. The HEMS team's knowledge about the energy value of selected foods was assessed based on the author's photographs of meals. The meals energy value was calculated using the applicable Polish tables of foods' nutritional value and content.

Results: The assessed group was characterized by a high share of overweight and obese persons. According to $\mathrm{BMI}, 34.6 \%$ of the tested persons had normal range body mass, $44.9 \%$ were overweight, and $20.5 \%$ were obese. An analysis of the respondents' answers showed that on average they overestimated energy value of six out of the seven presented meals. The overestimation concerned mainly the energy value of supper (over $215 \mathrm{kcal}$ ) and snack I (over $283 \mathrm{kcal}$ ). Those were meals including fast food, sweets and stimulants.

Tables: 3 - References: 22 - Full-text PDF: http://www.pjambp.com • Copyright (C 2016 Polish Aviation Medicine Society, ul. Krasińskiego 54/56, 01-755 Warsaw, license WIML • Indexation: Index Copernicus, Polish Ministry of Science and Higher Education 
Conclusions: The HEMS team's knowledge about the energy value of meals was unsatisfactory. The level of nutrition knowledge was independent of a person's profession, education, sex, and BMI. Nutrition education and healthy lifestyle programs should be implemented in the examined group.

Keywords: knowledge about energy value, Polish Medical Air Rescue, overweight, obesity

\section{INTRODUCTION}

An appropriate level of knowledge about nutrition, and the resulting proper diet is one of the components in health-promoting behaviors $[9,17]$. The profession of both paramedics and pilots should involve taking greater care of one's health. Both occupations require high mental and physical fitness in order to be able to act efficiently in stressful conditions. The fitness depends on numerous factors, one being proper nutrition. A well-balanced diet ensures wellness, facilitates recovery processes, provides protection against illnesses and improves the performance of the organism $[4,5,16]$. A condition of a well-balanced diet, apart from a proper supply of nutrients is a proper supply of calories. In order to maintain the body's energy balance, the quantity of the energy supplied to the organism must be equal to the spent energy [6]. Illnesses related to disorders of energy balance are a serious health problem. More than 1 billion adults and 100 million children in the world suffer from obesity or overweight [2]. Limiting calorie intake in the daily food ration, and thus generating a negative body's energy balance, is one of the crucial components of body weight reduction. Persons with excessive body weight are particularly encouraged to pay attention to the energy value of individual products and meals as well as to estimate the daily calorie intake [3]. Therefore, increasing the level of knowledge about nutrition is an important tool for stimulating proper eating behaviors, which prevent overweight and obesity [7]. However, as numerous studies prove, knowledge about nutrition does not always translate into eating habits and behaviors $[17,5,15]$. For instance, despite high social awareness and introduction of a variety of nutrition programs in Great Britain, its obesity rates continue to grow [10].

It is assumed in the study below that HEMS paramedics and pilots should be characterized by a high level of knowledge about nutrition due to their profession.

The aim of this study is to assess the Polish Medical Air Rescue paramedics and pilots' knowledge about nutrition with respect to the energy value of selected meals present in the daily diet.

\section{MATERIAL AND METHODS}

The assessment of the energy value of the selected meals was carried out among all Polish Helicopter Emergency Medical Service (HEMS) pilots and paramedics ( 66 pilots, 65 paramedics) at the age of 27-59. The majority of the respondents were men, while women constituted $3.8 \%$ (they were present only among paramedics).

Their nutritional status was assessed based on the results of anthropometric tests. Height and body weight were measured, which was the ground for calculating the height- and weight-based Body Mass Index (BMI), which was then interpreted according to the WHO classification [21].

The HEMS team's knowledge about the energy value of the selected meals was assessed based on the authors' photographs of meals: breakfast, lunch, dinner, high tea, supper and two snacks. The composition and energy value of the presented meals are included in Tab. 2.

The energy value of the meals was calculated based on the applicable Polish food composition and nutrition tables [8]. In order to analyze the results more precisely, the answers obtained from the HEMS team were divided into three categories: answer within the standard, answer below the standard and answer above the standard. An answer within the standard was considered one constituting $\pm 10 \%$ of the correct value. Answers below the standard were below this range, while answers above the standard were above this range. Four questionnaires were not subject to statistical analysis due to incomplete answers.

The STATISTICA 10.0 PL program was used for statistical analyses; the value of the statistical significance was assumed at the level of $p<0.05$. Average values, standard deviation, median, minimum and maximum values were calculated. Normal distribution was examined using the ShapiroWilk test, while the U Mann-Whitney and KruskalWallis non-parametric tests were applied for comparing the energy value of meals depending on the profession, education, and BMI. Relations between the analysis of answers by categories (a correct answer, an answer below the standard 
and above the standard) and the above variables were checked with the chi-square test.

Tab. 1. Description of the examined group.

\begin{tabular}{|c|c|c|c|}
\hline \multicolumn{2}{|l|}{ Variable } & \multicolumn{2}{|c|}{ Results } \\
\hline \multirow[t]{2}{*}{ Age [in years] } & $X \pm S D$ & \multicolumn{2}{|c|}{$42.8 \pm 9.6$} \\
\hline & $(\min -\max )$ & \multicolumn{2}{|c|}{$27.0-59.0$} \\
\hline \multirow[t]{2}{*}{ Body weight [in kg] } & $\mathrm{X} \pm \mathrm{SD}$ & \multicolumn{2}{|c|}{$86.2 \pm 14.7$} \\
\hline & $(\min -\max )$ & \multicolumn{2}{|c|}{$59.9-140.1$} \\
\hline \multirow[t]{2}{*}{ Height [in $\mathrm{cm}$ ] } & $X \pm S D$ & \multicolumn{2}{|c|}{$178.1 \pm 5.8$} \\
\hline & $(\min -\max )$ & \multicolumn{2}{|c|}{$164.0-195.0$} \\
\hline \multirow[t]{2}{*}{ BMI } & $\mathrm{X} \pm \mathrm{SD}$ & \multicolumn{2}{|c|}{$27.1 \pm 4.2$} \\
\hline & $(\min -\max )$ & \multicolumn{2}{|c|}{$19.7-42.9$} \\
\hline Sex: & \multicolumn{3}{|l|}{ (\%); n } \\
\hline women & & 3.14 & 4 \\
\hline men & & 96.85 & 123 \\
\hline Profession: & (\%); $\mathrm{n}$ & & \\
\hline pilot & & 53.5 & 68 \\
\hline paramedic & & 46.5 & 59 \\
\hline Education: & (\%); $\mathrm{n}$ & & \\
\hline higher & & 70.9 & 90 \\
\hline secondary & & 29.1 & 37 \\
\hline Place of residence: & (\%); n & & \\
\hline town/city & & 81.9 & 104 \\
\hline village & & 18.1 & 23 \\
\hline
\end{tabular}

$X$ - average value; SD - standard deviation; \% - percentage of respondents; $\mathrm{n}$ - number of respondents

Tab. 2. Assessment of the calorific value of individual meals.

\section{RESULTS}

The examined population was composed of 127 employees of the Helicopter Emergency Medical Service, $53.5 \%$ of whom were pilots and $46.5 \%$ were paramedics. The group under assessment was characterized by a high share of overweight and obese persons. BMI was proper in the case of only $34.6 \%$ of the tested persons, while $44.9 \%$ of them were overweight, and $20.5 \%$ were obese. Overweight and obesity were more common among pilots (60.2\%) than among paramedics (38.5\%). The majority of the respondents had higher education and came from towns/cities. A detailed description of the group in terms of somatic and demographic characteristics is presented in Tab. 1.

In analyzing the average values of the answers provided by the respondents when estimating the energy value of meals, it was found that they overestimated the energy value of six out of the seven presented sets (Tab. 2). The average answer below the correct value was provided only in the case of lunch. The respondents' most significant overestimations concerned the average energy value of supper (by over $215 \mathrm{kcal}$ ) and snack I (by over 283 kcal), that is meals consisting of fast food, sweets and stimulants. The respondents estimated the energy value of breakfast with the highest accuracy. The ranges presented in Tab. 2. (min - max) prove, however, a considerable diversity of the answers given by the respondents.

\begin{tabular}{|c|c|c|c|c|c|}
\hline Presented meals & Correct answer [kcal] & $\begin{array}{c}\text { Average answer } \\
\text { provided by the } \\
\text { respondents } \\
(X \pm S D) \\
(n=127)\end{array}$ & Median & \multicolumn{2}{|c|}{$\begin{array}{c}\text { Range } \\
\text { (min- } \max )\end{array}$} \\
\hline $\begin{array}{l}\text { Breakfast } \\
\text { ( } 2 \text { slices of brown bread with } \\
\text { butter, a poultry cabanos } \\
\text { sausage, an egg, a tomato) }\end{array}$ & 473 & $507.6 \pm 341.7$ & 450.0 & 30.0 & 2000.0 \\
\hline $\begin{array}{l}\text { Lunch } \\
\text { (a bilberry bun, an apple) }\end{array}$ & 444 & $352.1 \pm 208.5$ & 300.0 & 30.0 & 1200.0 \\
\hline $\begin{array}{l}\text { Dinner } \\
\text { (a minced poultry cutlet, pota- } \\
\text { toes, beetroots, apple juice) }\end{array}$ & 675 & $800.3 \pm 703.3$ & 700.0 & 150.0 & 7000.0 \\
\hline $\begin{array}{l}\text { High tea } \\
\text { ( } 3 \text { pancakes with cottage } \\
\text { cheese) }\end{array}$ & 472 & $557.3 \pm 490.3$ & 450.0 & 60.0 & 4500.0 \\
\hline $\begin{array}{l}\text { Supper } \\
\text { (pizza, beer) }\end{array}$ & 1,045 & $1260.6 \pm 1,362.6$ & 950.0 & 115.0 & 14000.0 \\
\hline $\begin{array}{l}\text { Snack I } \\
\text { ( } 5 \text { chocolate covered } \\
\text { marshmallows, coffee with a } \\
\text { teaspoon of sugar) }\end{array}$ & 284 & $567.8 \pm 984.1$ & 350.0 & 40.0 & 10500.0 \\
\hline $\begin{array}{l}\text { Snack II } \\
\text { (3 Jaffa cakes) }\end{array}$ & 168 & $261.9 \pm 458.3$ & 150.0 & 15.0 & 4500.0 \\
\hline Total & 3560 & $4307.7 \pm 4156.6$ & 3390.0 & 510.0 & 43150.0 \\
\hline
\end{tabular}

$\mathrm{X}$ - average value; SD - standard deviation; $\mathrm{n}$ - number of respondents; min - minimum; max-maximum 
The analysis of answers in individual categories (answers within the standard, answers below the standard, answers above the standard) showed that the answers within the standard were given by the smallest percentage of the respondents (from $13 \%$ to $24.4 \%$ depending on the presented meal). Nearly half of the respondents underesti-

Tab. 3. Estimation of the calorific value of individual meals by answers within the standard, answers below the standard and answers above the standard $(\mathrm{N}=127)$.

\begin{tabular}{|c|c|c|c|}
\hline Presented meal & $\begin{array}{l}\text { Answers within } \\
\text { the standard }\end{array}$ & $\begin{array}{l}\text { Answers } \\
\text { below the } \\
\text { standard }\end{array}$ & $\begin{array}{l}\text { Answers above } \\
\text { the standard }\end{array}$ \\
\hline \multicolumn{4}{|l|}{$\begin{array}{l}\text { Breakfast (473 } \\
\text { kcal) }\end{array}$} \\
\hline $\mathrm{N}$ & 28 & 62 & 37 \\
\hline Percent & 22 & 48.8 & 29.1 \\
\hline $\mathrm{X} \pm \mathrm{SD}$ & $488.6 \pm 20.9$ & $275.6 \pm 95.3$ & $910.8 \pm 364.4$ \\
\hline$(\min -\max )$ & $450-500$ & $30-400$ & $550-2,000$ \\
\hline \multicolumn{4}{|l|}{ Lunch (444 kcal) } \\
\hline $\mathrm{N}$ & 17 & 82 & 28 \\
\hline Percent & 13.4 & 64.6 & 22 \\
\hline $\mathrm{X} \pm \mathrm{SD}$ & $425.9 \pm 29.2$ & $231.4 \pm 91.1$ & $660.7 \pm 176.0$ \\
\hline$(\min -\max )$ & $400-480$ & $30-380$ & $500-1,200$ \\
\hline \multicolumn{4}{|l|}{ Dinner (675 kcal) } \\
\hline$N$ & 27 & 49 & 51 \\
\hline Percent & 21.3 & 38.6 & 40.2 \\
\hline$X \pm S D$ & $668.5 \pm 50.3$ & $385.5 \pm 113.5$ & $1268.6 \pm 911.6$ \\
\hline$(\min -\max )$ & $600-750$ & $150-550$ & $800-7,000$ \\
\hline \multicolumn{4}{|l|}{$\begin{array}{l}\text { High tea (472 } \\
\text { kcal) }\end{array}$} \\
\hline$N$ & 21 & 62 & 44 \\
\hline Percent & 16.5 & 48.8 & 34.6 \\
\hline $\mathrm{X} \pm \mathrm{SD}$ & $481.0 \pm 24.9$ & $302.9 \pm 95.5$ & $952.3 \pm 659.9$ \\
\hline$(\min -\max )$ & $450-500$ & $60-400$ & $550-4,500$ \\
\hline \multicolumn{4}{|l|}{$\begin{array}{l}\text { Supper (1,045 } \\
\text { kcal) }\end{array}$} \\
\hline$N$ & 21 & 62 & 44 \\
\hline Percent & 16.5 & 48.8 & 34.6 \\
\hline $\mathrm{X} \pm \mathrm{SD}$ & $1033.3 \pm 63.9$ & $663.6 \pm 206.7$ & $2210.2 \pm 1978.9$ \\
\hline$(\min -\max )$ & $950-1,150$ & $115-900$ & $1,200-14,000$ \\
\hline \multicolumn{4}{|l|}{ Snack I (284 kcal) } \\
\hline $\mathrm{N}$ & 16 & 32 & 79 \\
\hline Percent & 12.6 & 25.2 & 62.2 \\
\hline $\mathrm{X} \pm \mathrm{SD}$ & $286.9 \pm 15.4$ & $179.0 \pm 51.8$ & $782.2 \pm 1199.4$ \\
\hline$(\min -\max )$ & $260-300$ & $40-250$ & $320-10500$ \\
\hline \multicolumn{4}{|l|}{ Snack II (168 kcal) } \\
\hline$N$ & 31 & 43 & 53 \\
\hline Percent & 24.4 & 33.9 & 41.7 \\
\hline $\mathrm{X} \pm \mathrm{SD}$ & $150.0 \pm 0.0$ & $87.6 \pm 25.7$ & $468.9 \pm 657.3$ \\
\hline$(\min -\max )$ & $150-150$ & $15-120$ & $200-4500$ \\
\hline
\end{tabular}

$\mathrm{X}$ - average value; SD - standard deviation; $\mathrm{n}$ - number of respondents; min-minimum; max-maximum mated the energy value of breakfast, high tea, and supper (Tab. 3). The majority of the respondents (64.6\%) underestimated the energy value of lunch, too. Snack I (coffee with a teaspoon of sugar and 5 chocolate covered marshmallows) turned out to be the meal the energy value of which was most frequently overestimated (62.2\%). The overestimated values of snack I arose from the fact that the majority of the respondents did not know that the energy value of coffee is very low $(9 \mathrm{kcal} / 100 \mathrm{~g}$ - Kunachowicz et al.), which resulted in a significant overestimation of the energy value of the whole presented meal.

No relation between indications of the energy value of meals as well as answers in the categories (answers within the standard, answers below the standard, answers above the standard) and profession, education and state of nutritional status as per BMI ( $p>0.05$ ) was observed.

\section{DISCUSSION}

Maintaining a good psychophysical condition by the HEMS team is indispensable for pursuing this profession. Undertaking health-promoting behaviors, including compliance with appropriate dietary recommendations, prevents absence from work due to illnesses, reduces health care costs, and increases the operating efficiency of individuals and entire organizations [12].

The Polish Medical Air Rescue population is characterized by a low knowledge about the energy value of meals. Merely one in four examined persons provided an answer within the standard. It is particularly worrying as excessive body weight was found in more than $65 \%$ of the tested persons from the group under analysis. It was proved in the Polish National Multi-Centre Health Survey (Wieloośrodkowe Ogólnopolskie Badanie Stanu Zdrowia Ludności) (2010) that Poles' knowledge about nutrition is at a very low level, which is consistent with the obtained results of the authors' research. It was expected that paramedics, due to their medical education, would be characterized by better knowledge about nutrition than pilots. However, no statistically significant differences as to the level of knowledge between the groups were found ( $p>0.05)$. The authors' results are confirmed by other researchers, who proved that health behaviors, including eating behaviors, of paramedics do not differ from health behaviors in the control group in a statistically significant manner [11]. A low level of knowledge about nutrition was also recorded in other groups, such as military volunteers [4], athletes [18], so persons 
who should take care of proper nutrition and have knowledge in this respect. In contrast, the study by Kayapinar and Savas [5] found that the level of knowledge about nutrition among police officers was satisfying although it did not translate into eating behaviors in that group. In the authors' research, education of the respondents did not determine their level of knowledge about the energy value of the presented meals either. Similar results were obtained in the study by Bleich and Pollack [1], which was conducted on 663 adults in the United States of America.

Like in the authors' research, no significant differences between the level of knowledge about nutrition and the BMI value were stated in the study by O'Brien and Davies [10] as well as Bleich and Pollack [1]. O'Brien and Davies [10] imply also that the deficit of knowledge about nutrition is not the most important factor in overweight and obesity prevention. Yet it was proved in the study by Shimokawa [14] that a higher level of knowledge about nutrition contributed to reducing calorie intake, which directly prevents excessive body weight gains. Additionally, the researcher proved that the level of such knowledge differs among overweight persons and those with proper body weight. Like in the study by Shimokawa [14], a relationship between the respondents' BMI and their knowledge about nutrition was proved in the study by Shah at al. [13]. The higher the BMI of the examined persons, the more commonly they overestimated the size of the food portions presented in the study, with the relationship being statistically significant ( $p$ within the range from 0.1 to 0.3 depending on the meal).

Sex can be also one of the factors determining the level of knowledge about nutrition. It was stated in the study by York-Crowe et al. [22] that women were characterized by a higher level of knowledge about nutrition in comparison to men. Hence, the low level of knowledge about nutrition in the analyzed group can be explained by the fact that the vast majority of the examined HEMS team were men.

\section{CONCLUSIONS}

1. The HEMS team's knowledge about the energy value of meals was unsatisfactory.

2. The level of knowledge about nutrition was independent of a person's profession, education, sex, and BMI.

3. It is worth implementing nutrition education and healthy lifestyle programs in the examined group.

\section{AUTHORS' DECLARATION:}

Study Design: Agata Gaździńska, Mariusz Wyleżoł; Data Collection: Agata Gaździńska, Paweł Jagielski, Robert Gałązkowski; Manuscript Preparation: Agata Gaździńska, Mariusz Wyleżoł, Paweł Jagielski; Funds Collection: Robert Gałązkowski. The Authors declare that there is no conflict of interest.

\section{REFERENCES}

1. Bleich SN, Pollack KM. The publics' understanding of daily caloric recommendations and their perceptions of calorie posting in chain restaurants. BMC Public Health, 2010, 10:121. http://www.biomedcentral.com/1471-2458/10/121.

2. Burdge GC, Lillycrop KA. Environment-physiology, diet quality and energy balance: The influence of early life nutrition on future energy balance. Physiology \& Behavior, 2014, http://dx.doi.org/10.1016/j.physbeh.2013.12.007.

3. Forwood SE, Ahern A, Hollands GJ, Fletcher PC, Marteau TM. Underestimating Calorie Content When Healthy Foods Are Present: An Averaging Effect or a Reference-Dependent Anchoring Effect? PLoS ONE. 2013; 8(8): 71475. doi:10.1371/journal. pone.0071475.

4. Herzman-Harari S, Naama Constantini N, Gideon Mann G, Lencovsky Z, Stark AH. Nutrition Knowledge, Attitudes, and Behaviors of Israeli Female Combat Recruits Participating in a Nutrition Education Program. Military Medicine, 2013; 178: 517-522.

5. Kayapinar FC, Savas B. Nutrition knowledge levels of police officers (An example study). Procedia - Social and Behavioral Sciences, 2012; 47: 1232-1236. 
6. Kinalska I, Popławska - Kita A, Telejko B, Kinalski M, Zonenberg A. Obesity and carbohydrate metabolism disorders. Endocrinology, obesity, metabolic disorders. 2006; 2: 94-101.

7. Klohe-Lehman DM., Freeland-Graves J, Anderson ER, McDowell T, Clarke KK, Hanss-Nuss H, Cai G, Puri D, Milani T J. Nutrition Knowledge is associated with greater weight loss in obese and overweight low-income mothers. Journal of the American Dietetic Association. 2006; 106: 65-75.

8. Kunachowicz H, Nadolna I, Iwanow K. Food composition and nutrition tables. Warszawa: PZWL; 2005.

9. Mojs E, Strzelecki W, Kleka P, Samborski W, Gajewska E, Sobieska M, Kalmus G. The impact of a stress management strategy on health behaviours of the children and youth treated in sanatoria due to obesity. Nowiny Lekarskie 2011, 80(6):, 423-428.

10. O'Brien G, Davies M. Nutrition Knowledge and body mass index. Health Education Research, 2007; 22: 571-575.

11. Piotrowski A, Mazurkiewicz P. Health promoting behaviours in the Prison Service against other uniformed groups. Przegląd więziennictwa polskiego, 2012; 76-77: 119-139.

12. Plat M J, Friengs - Dresen MH, Sluiter JK. A systematic review of job-specific workers' health surveillance activities for firefighting, ambulance, police and military personnel. International Archives of Occupational and Environmental Health, 2011; 84: 839-857.

13. Shah M, Beverley Adams-Huet B, Elston E, Hubbard S, Carson K. Food Serving Size Knowledge in African American Womenand the Relationship with Body Mass Index. Journal of Nutrition Education and Behavior, 2010; 42: 99-105.

14. Shimokawa S.When does dietary knowledge matter to obesity and overweight prevention? Food Policy, 2013; 38: $35-46$.

15. Stafleu A, Van SW, DE Graaf C, Burema J, Hautvast J. Nutrition knowledge and attitudes towards high fat foods and low-fat alternatives in three generations of women. European Journal of Clinical Nutrition. 1996; 50: 33-41.

16. Stark AH, Weis N, Chapnik L, Barenboim E, Reifen R. Dietary Intake of Pilots in the Israeli Air Force. Military Medicine. 2008; 173: $780-784$.

17. Szczepańska E, Brończyk - Puzoń A, Skrzypek M. Knowledge and selected eating behaviours of obese patients depending on their level of education. Problemy Higieny i Epidemiologii. 2013; 94: 802-806.

18. Torres-McGehee TM., Pritchett KL, Zippel D, Minton DM, Cellamare A, Sibillia M. Sports Nutrition Knowledge Among Collegiate Athletes, Coaches, Athletic Trainers, and Strength and Conditioning Specialists. Journal of Athletic Training, 2012; 47: 205-211.

19. Waśkiewicz A, Piotrowski W, Sygnowska E. i wsp. Quality of nutrition and health knowledge in subjects with diagnosed cardiovascular diseases in the Polish population- National Multicentre Health Survey (WOBASZ). Kardiologia Polska. 2008; 66: 507-513.

20. Waśkiewicz A. The quality of nutrition and level of health knowledge among young adult Poles - Polish National Multi-Centre Health Survey (WOBASZ). Problemy Higieny i Epidemiologii. 2010; 91: 233-237.

21. WHO. Obesity: preventing and managing the global epidemic: report of a WHO consultation (ISSN 05 12-3054): WHO; Geneva, Switzerland; 1999. WHO Tech Rep Ser, 894.

22. York-Crowe EE, White MA, Paeratakul S, Williamson DA. The diet and health knowledge survey: Development of a short interview format. 2006.

\section{ACKNOWLEDGEMENTS}

The views, opinions, and findings contained in this article are our own and should not be construed as an official Polish Air Force position, policy, or decision, unless so designated by other official documentation.

Cite this article as: Gaździńska A, Gałązkowski R, Jagielski P, Wyleżoł M. Assessment of Knowledge about The Energy Value of Selected Meals by The Helicopter Emergency Medical Service (Hems) Team. Pol J Aviat Med Bioeng Psychol 2016; 22(3): 12-17. DOI: 10.13174/ pj ambp. 12.07.2017.02 